\title{
Female Invisibility in the Male's World of Plantation-Era Tropical North Queensland
}

\author{
Bianka Vidonja Balanzategui \\ James Cook University
}

\begin{abstract}
Australian rural history accounts abound with the admirable, foolhardy and often savage exploits of white male protagonists, while women, white or of colour, are generally invisible. This is despite the fact there is a substantial primary record of the history of European settlement in rural Australia. Taking the Herbert River Valley, located in tropical north Queensland, as a case study, this article fleshes out the scant detail of the women who, alongside the men, battled life on the frontier of European incursion into Indigenous Country. It will focus on the experiences of three women: Manbarra woman Jenny, Melanesian indentured labourer Annie Etinside, and Australian-born Chinese woman Eliza Jane Ah Bow, and how their lives were enmeshed with those of white women who lived alongside them in the Herbert River Valley in the late nineteenth century. These women were hardly bystanders and observers but active participants in the drama of colonisation that melded cultures from across the globe.
\end{abstract}

Women lived in the Herbert River Valley, in the north Kennedy district of tropical north Queensland, from the beginning of European incursion in the area in the late nineteenth century. ${ }^{1}$ Among them was Manbarra woman Jenny, Australian-born Chinese woman Eliza Jane Ah Bow and Melanesian indentured labourer Annie Etinside, as well as white women Isabella Mackenzie, Isabella Campbell, Elizabeth Burrows and Louisa Buchanan. Such women have often been invisible in the historical record as European men, who penned the majority of this history, did not see women beyond their domestic arrangements. The admirable, foolhardy

1 Herbert River Valley hereafter referred to as the Herbert. 
and often savage exploits of white male protagonists abound in Australian rural history accounts. Due to the predominance of men in frontier society, the 'frontier' is assumed to have been a masculine space. However, the significance of women's presence, and what they did, needs to be addressed. The recorded history of the Herbert contains tantalising hints but few details of the women who battled life on the frontier alongside men. This article fleshes out the scant sources on the lives of both white women and women of colour in the Herbert to reveal the diverse ethnic makeup of its female population, thereby providing a new gendered approach to the topic. It will be argued that the women were not passive bystanders and observers but protagonists in the events that played out on the Herbert upon European settlement.

Fleshing out the lives of white women - let alone women of colour-from the few women's memoirs and men's records that remain is no easy task, the more so because they were rural women. Helen Gregory argues that for a long time, rural women were overlooked in feminist historiography. Though Gregory successfully locates rural women and their contributions, she includes only one woman of colour in her study-Dalleburra woman Wyma of central north Queensland. ${ }^{2}$ Majorie Gilmore, writing of the pioneering Atkinson family, and myself, writing of the history of the Herbert, pay ample tribute to European women, their talents, hospitality, energy and bravery. Those European women may be identified and named but Bandyin, Njawaygi, Warrgamay, Melanesian and Chinese women remain faceless. ${ }^{3}$ It is inarguably more challenging to elaborate on the lives of women of colour than those of white women. Kay Saunders argues that in settler accounts of interactions with Indigenous people generally all 'Blacks' were seen as male, making black women invisible. ${ }^{4}$ The same could be said of the Melanesian and Chinese people on the Herbert.

Today, on the Herbert, both academic and family historians are endeavouring to tell the stories of people of colour. In 2017 Gugu Badhun elder and academic Yvonne Cadet-James, together with Robert Andrew James, Sue McGinty and Russell McGregor, published a work that bridged historical scholarship and Indigenous oral tradition to tell the other side

2 Helen Gregory, “The Hearts That Made the Nation”: Fleshing out the Stereotype', Royal Historical Society of Queensland Journal, 20, no. 5 (February 2008): 160.

3 Bianka Vidonja Balanzategui, The Herbert River Story (Ingham: Hinchinbrook Shire Council, 2011).

4 Kay Saunders, 'All the Women Were White? Some Thoughts on Analysing Race, Class and Gender in Australian History', Hecate, 17, no. 1, (31 May 1991): 157. 
of the story of white settlement of the Valley of Lagoons. ${ }^{5}$ Through family and scholarly research, Albert and Rachel Garlando have told the story of a Melanesian woman in the plantation period. ${ }^{6}$ Historian Sandi Robb, working with the Ingham Family History Association, identified both Chinese men and women who lived and worked on the Herbert during the plantation era. ${ }^{7}$ These accounts affirm the significant roles played by women in the late nineteenth century on the Herbert.

This article will argue that despite their invisibility in nineteenth-century records, women, both white and of colour, were vital to sustaining and advancing human endeavour on the Herbert during the plantation era. That they were protagonists is a novel interpretation of plantation life. The protagonists are usually portrayed in the contemporary records as brave and adventurous white men assisted by faceless men of colour. Nineteenthcentury men, living on the Herbert, may have mentioned particular white women in passing in their accounts, but it has not been til the twenty-first century and in research conducted by women that individual women of colour have been identified. This article is significant because for the first time a group of women - white and of colour, living alongside each other in plantation-era tropical north Queensland-have been identified, their lives fleshed out and their contributions acknowledged.

\section{Where are the Women? Male and Female Record Keeping on the Herbert}

The Herbert was opened to pastoralism and plantation agriculture after the explorer George Elphinstone Dalrymple reported favourably on its economic potential in 1864. The vanguard of European settlers arrived in 1868 and began clearing the traditional lands of the Bandyin, Njawaygi and Warrgamay peoples. ${ }^{8}$ The Herbert settlement, with its administrative centre at Cardwell, was then at the extreme limit of European settlement on the north-eastern coast of Australia. Sugar planters were followed by

5 Yvonne Cadet-James, Robert Andrew James, Sue McGinty and Russell McGregor, Gugu Badhun: People of the Valley of Lagoons (Canberra: AIATSIS Research Publications, 2017).

6 Rachel Garlando, 'Annie Gosling and a Family Living Outside the South Sea Islander Experience', Assessment paper, 2 November 2018, James Cook University, Townsville.

7 Re-Discovering 'BUK TI' presented by the Ingham Family History Association Inc.

8 Bianka Vidonja Balanzategui, 'Small Sugar Farmer Agency in the Tropics 1872-1914 and the Anomalous Herbert River Farmers' Association', (PhD thesis, James Cook University, 2019), 168-71. 
small selectors who were not daunted by the remoteness of the Herbert. Among the first of the white interlopers on the lands of the Gugu Badhun was the Valley of Lagoons partnership of Dalrymple and Arthur and Walter Scott, west of Cardwell. They moved sheep and cattle onto the property and appointed Henry Worsley Stone to manage the Vale of Herbert waystation, located in Warrgamay Country (halfway between Cardwell and Valley of Lagoons). Stone set up the waystation in 1864 becoming the first European settler on the Herbert. Neither he nor the Scotts were accompanied by spouses or female relatives.

Despite a substantial extant primary record of the nineteenth-century European presence in the Herbert, and the role of white men in establishing that settlement, it is hard to locate women as active protagonists. ${ }^{9}$ In her study of Sydney business women during the same period, Catherine Bishop comments that 'male diarists did not seem to see women' ${ }^{10}$ Likewise, north Queensland literary scholars Cheryl Taylor and Elizabeth Perkins attribute women's invisibility in men's records to an instinctive adherence to 'the code of contemporary British men in rarely mentioning women or children or domestic arrangements'. ${ }^{11}$ As for businesswomen, Bishop suggests that men did not mention them in their writings because they did not regard the small businesses that women ran as significant in the same way they regarded larger businesses run by men. ${ }^{12}$ In writings of men from the Herbert, white women were referenced with pity, while women of colour, if mentioned at all, were often described with amusement or contempt; sometimes their difficulties—including domestic violence-were significantly trivialised or downplayed. ${ }^{13}$ For example, Walter Scott, commenting on Stone's

9 Robert Arthur Johnstone, Spinifex \& Wattle: Reminiscences of Pioneering in North Queensland Being the Experiences of Robert Arthur Johnstone (East Melbourne: JW Johnstone-Need, 1984); J A B Diary, 'Robert Mitchell Boyd (1849-1912)', connorhistorycom.files.wordpress.com/2017/12/boyd-robertmitchell-boyd-1849-1912-references.pdf; Arthur Neame, The Diary of Arthur Neame, 1870-1897, ed. Sydney May (Aitkenvale: Terry Lyons, 2003); Jas Cassady for FA Cassady, JC/1 Original notebook James Cassady Archive, Special Collections, James Cook University, Townsville; John Alm, Early History of the Herbert River District being 'The Memoirs of the Early Settlement of the Lower Herbert and the Start and Progress of the Sugar Industry in the District, 1932/33/35' (Aitkenvale: Terry Lyons, 2002); Alec S Kemp, The Kemp Report, unpublished text, n.d.; T Weitemeyer, Missing Friends: Being the Adventures of a Danish Emigrant in Queensland (1871-1880) (London: T Fisher Unwin, 1892).

10 Catherine Bishop, Minding Her Own Business: Colonial Businesswomen in Sydney (Sydney: UNSW Press, 2015), 11.

11 Cheryl Taylor and Elizabeth Perkins, 'Warm Words; North Queensland Writing', in By the Book: A Literary History of Queensland, eds. Patrick Buckridge and Belinda McKay (Brisbane: University of Queensland Press, 2007), 219, doi.org/10.20314/als.d3884732cb.

12 Bishop, Minding Her Own Business, 11-12.

13 See, for example, Walter Scott to station manager, Frederic Beazley, Correspondence, 17 December 1886, Valley of Lagoons Station Deposit, Noel Butlin Archives Centre [hereafter NBAC], M27. 
apparent heavy drinking and his treatment of his housekeeper Maria, the wife of stockman Duncan McAuslan, wrote in a letter: 'I am sorry to hear Mrs McAuslan has had a bad time'. Norwegian anthropologist Carl Lumholtz met Nelly, the Aboriginal wife of a Melanesian labourer in 1882. The Melanesian labourer was the nominal housekeeper for the caretaker of the Vale of Herbert property, but Lumholtz noted that the burden of the work fell on Nelly. Lumholtz's descriptions of Nelly are largely tongue-incheek, and lacking any real empathy with the brutality of her existence. In his opinion 'her existence was a happy one, marred only by an occasional flogging from her husband'. ${ }^{14}$

However, not all men were so dispassionate. Pastoralist James Cassady recounted with rage how he took in another Indigenous woman named Nelly, who was viciously wounded by a trooper of the Native Mounted Police (a paramilitary force used as a means of control, and generally consisting of a group of Aboriginal trackers under the command of European officers). ${ }^{15} \mathrm{He}$ attended to her, giving her food and tending to her health for 10 weeks. ${ }^{16}$ In letters to close relatives, men could be less guarded, and thus these sources often contained more personal details about the lives of the women they lived with. Pastoralist Henry Atkinson of Wairuna (adjacent to Valley of Lagoons) wrote to his brother to tell him that he and his wife had just farewelled a stillborn baby. He wrote:

Little baby died on Monday night perhaps it was as well coming as it did before its time but it is hard to lose them. Isabel is doing well. She is quite cheerful—unless her breasts give trouble which I don't anticipate she will soon be quite well. I want you to come over, you will cheer the girls up a bit $\&$ I want a chat on business. I can't leave as I have to act baby and draw Isabel's milk. ${ }^{17}$

14 Carl Lumholtz, Among Cannibals: Account of Four Years Travels in Australia, and of Camp Life with the Aborigines of Queensland (Canberra: Australian National University Press, 1980), facsimile of 1888 edition, 89.

15 Jonathan Richards, The Secret War: A True History of Queensland's Native Police (Brisbane: University of Queensland Press, 2008).

16 'The Way We Civilise', Brisbane Courier, 27 October 1880, Trove, National Library of Australia; James Cassady to Colonial Secretary, 1 May 1880, Queensland State Archives [hereafter QSA], $847023,80 / 2307$.

17 Henry Atkinson to Tom Atkinson, Wairuna Letterbook, letter number 554, 2 November, 1898, quoted in Majorie Gilmore, On Eagles Wings: The Atkinsons of North Queensland 1862-2014 (Peregian Beach: Queensland, Tableland Research and Consultancy Services, 2015), 123. 
On the whole, however, men predominantly recorded their own and other men's exploits, or the daily running of their properties. Women's invisibility in those records insinuates a lack of agency; in reality, women in the Herbert were integral to the everyday running of properties, and had multifarious skills men depended on.

Women's records are very different in tone to men's recounts and offer intimate glimpses into their everyday lives on the Herbert. Their writings convey both the emotional and material hardship of family life on the colonial frontier. The diaries of Violet Wickham, who lived in the Herbert for nine years with her planter husband, and Augusta (Gussie) Feldt, a Swedish immigrant and the wife of a small farmer, reveal that women could nevertheless retain an indefatigable sense of humour. Violet, commenting on the double tragedy of losing her house in a fire and then damage to the next in a cyclone, wrote: 'Having been burnt out it seemed necessary for me to try the water cure'. ${ }^{18}$ Gussie had a droll turn of phrase. In the teeth of a cyclone she and her husband lay fearfully on the bed with the big lamp under the little dressing-table and the Ansonia clock on top of the table. Every time a big jerk shook the house, out went the lamp and the clock was like a man who was hesitant to write out a cheque. ${ }^{19}$

Women also left a variety of other written sources. Planter's wife Eliza Agnes Boyd kept a recipe book that included medical treatments for family and labourers. Those treatments are a clear example of the assistance women could provide in the absence of professional medical help. The book also contains, most poignantly, a pattern for baby's booties; Eliza would not only bury a child on the Herbert but die there in childbirth. ${ }^{20}$ Even when such records exist, they cannot always be accessed. Letters written by Stone's wife Anna are very frank. Because the custodians feel the comments about individuals may offend their descendants, the letters are under restricted access. ${ }^{21}$ Les Pearson, who was able to circumvent this restriction, writes that the letters reveal that Eliza was a skilled tailoress who made all her own clothes, as well as those for her extended family and husband. Sadly, she never birthed a live baby, and referred to her

18 Violet Wickham, A Lady's Experience in Many Lands as quoted in Edward V Lane, 'Life and work of Henry Wickham', V-'Pioneering in north Queensland', The India-Rubber Journal, 2 January 1954, 18. Another example includes Kate Atkinson Diary, Virginia Bowman collection, Mudgee, NSW.

19 Augusta (Gussie) Feldt, Gussie’s story, unpublished typescript, 17.

20 Receipt Book, E A B, connorhistorycom.files.wordpress.com/2020/02/eliza-agnes-boyd-receiptbook-transcript.pdf.

21 Les Pearson, Henry Stone: A Pioneer with Dalrymple (Brinsmead: L M Pearson, 2007), 24. 
still-born babies as her 'little mites'. ${ }^{22}$ Occasionally women writers visited the Herbert and observed women in a way that men seldom did. Marion Ellis Rowan, the renowned author and traveller, attending an 'amusing' agricultural show in the town of Ingham observed 'mothers ... nursing their babies in most delightful unconcern'. ${ }^{23}$ The surviving memoirs, letters, recipe books and reportage of women who either lived on, or visited, the Herbert provide intimate details of daily life and confirm the range of tasks women undertook. They provide a first-hand account of the physical dangers and emotional toll of living and working in tropical Queensland during the plantation era.

\section{White Women on the Herbert}

While past writers have presented the economic development of the Herbert as a triumphal, white male endeavour, women were there from when the very first stick of cane was planted. If any women are identified in men's records by name and deed it is white women. The first mention of a white woman on the lower Herbert was Italian housekeeper Caterina Cordelia, who worked for licensed surveyor, Maurice Geoffrey O'Connell, his brother John Geoffrey and William McDowall (McDowell). ${ }^{24}$ Caterina was the first of many Italians to make the Herbert their home. First welcomed in the plantation era, as restrictions on the use of Melanesian indentured labour tightened, they were regarded as swarthy enough to be a suitable replacement labour while simultaneously conforming to prevailing ideals of whiteness. Italians, therefore, occupied a dichotomous space in Australia in the attribution of whiteness, especially with the enactment of the White Australia Policy in $1901 .^{25}$ Caterina and her

\section{Ibid.}

23 Marion Ellis Rowan, A Flower-Hunter in Queensland and New Zealand (London: John Murray 1898), 25-6.

24 Kemp, The Kemp Report, 5. Geographically, the lower Herbert area extends from the Seaforth Delta to the junction of the Herbert and the Stone Rivers. Later, lower Herbert came to mean the reach of the river between the town of Ingham, and the Herbert's mouth at Seaforth.

25 Lara Palombo, 'Whose Turn Is It? White Diasporic and Transnational Practices and the Necropolitics of the Plantation and Internment Camps', Australian Critical Race and Whiteness Studies Association, 3 (2007): 1-20; Catherine Dewhirst, 'Collaborating on Whiteness: Representing Italians in Early White Australia', Journal of Australian Studies, 32, no. 1 (2008): 33-49, doi. org/10.1080/14443050801993800; Jane Carey, Leigh Boucher and Katherine Ellinghaus, 'Historicising Whiteness: Towards a New Research Agenda', in Historicising Whiteness: Transnational Perspectives on the Construction of an Identity, eds. Leigh Boucher, Jane Carey and Katherine Ellinghaus (Melbourne: RMIT Publishing in association with the School of Historical Studies, University of Melbourne, 2007). 
companions arrived on the lower Herbert in 1868 when Indigenous people were still cautiously watching their activities from a distance. ${ }^{26}$ The men came to plant sugar but had no designs for a mill or any idea who would crush their cane. There were no public facilities as the European population numbered little more than 12 people. ${ }^{27}$ How Maurice inveigled Caterina to accompany him will forever remain a mystery, but there is no doubting her fearlessness and sense of adventure. 'Housekeeper' could be a euphemism for a more intimate relationship and some infatuation on the part of O'Connell is indicated by several landscape features, namely a creek and a hill, being named after his housekeeper. What happened to the O'Connells and McDowall after their brief stay on the Herbert can be tracked through newspaper reports and documents, but Caterina Cordelia remains an enigma. She epitomises the invisible white woman in plantation-era tropical north Queensland.

The next white woman on the Herbert that can be profiled from the male record is 28-year-old Isabella Mackenzie. She arrived in Cardwell in 1870 and was accompanied by her large extended family. She and two of her brothers moved to the lower Herbert in $1871 .{ }^{28}$ In that year, the European population of the upper and lower Herbert numbered 140 males and 29 females, the Melanesian numbered 63, and the Indigenous population less than $500 .{ }^{29}$ Unlike the O'Connell party, the Mackenzies had the knowledge and access to capital required to establish the first sugar plantation and mill on the Herbert (Gairloch) and used both Indigenous workers and indentured Melanesian labourers to clear the land and establish their mill. Isabella Mackenzie did not lack in means or courage. She owned plantation land, lived in a rough cottage and, soon after her arrival on the Herbert, raced others overland on horseback to Cardwell to the Land Agent's Office there-a difficult rough journey over the Seaview Range-to secure title to a selection for a friend. ${ }^{30}$ Nevertheless, when drinker and hot-head William Stewart obtained the

26 'Bowen', Queenslander, 16 January 1869, 5 (Trove); 'The Flaneur in Sydney', Empire (Trove), 16 January 1869,5 .

27 'Cardwell and the Vale of Herbert', Queenslander (Trove), 23 September 1871, 10.

28 Kemp, The Kemp Report, 5.

29 Douglas R Barrie, Minding My Business: The History of Bemerside and the Lower Herbert River District of North Queensland Australia (Ingham: Douglas R. Barrie, 2003), 28; Kay Saunders, Workers in Bondage: The Origins and Bases of Unfree Labour in Queensland 1824-1916 (Brisbane: University of Queensland Press, 1982), Table 4, 48; Helen Brayshaw, Well Beaten Paths: Aborigines of the Herbert Burdekin District, North Queensland. An Ethnographic and Archaeological Study (Townsville: James Cook University, 1990), 32.

30 Barrie, Minding My Business, 25. 
manager's position at Gairloch, he and Isabella quickly married. ${ }^{31}$ As the ratio of males to females was eight to one, Isabella would not have lacked for choice. ${ }^{32}$ Why she rushed into marriage with a ne'er-do-well puzzled even her contemporaries. Planter Arthur Neame, owner of Macknade, wrote in his diary that Isabella's marriage to William was 'much to the astonishment of everyone. It did not result in a happy life for her'. ${ }^{33}$ Isabella's daughter Elizabeth Charlotte was born on 7 June 1875 and in the same year Gairloch plantation was repossessed by the bank. ${ }^{34}$ Isabella and her husband William vainly tried to continue farming but then left the district. ${ }^{35}$

Isabella Mackenzie was accompanied by a female companion, 32-yearold widow Isabella Campbell, and her three children. A little more is known about her because her daughter wrote a short reflection on life on the Herbert in the late nineteenth century. ${ }^{36}$ Isabella Campbell also married soon after arrival on the Herbert. Like other single women and widows, she had made the hazardous journey to frontier areas to start a new life. In times when women depended on men for social security, widows, especially those with children to support, were impelled to find a new husband as soon as possible and nowhere was that more likely than on the frontier where women were few. Being accompanied by children was no impediment. Historian Katie Spearritt notes that in the years 1859 to 1889 Queensland had the highest marriage rate of the colonies. In the Kennedy district, between 80 and 90 per cent of women were married. ${ }^{37}$ It is perhaps understandable then that Isabella Campbell married immediately after she alighted from the ship in Cardwell given that she was a widow with young children to support.

\footnotetext{
31 Neame, Diary of Arthur Neame, 34.

32 Katie Spearritt, 'The Sexual Economics of Colonial Marriage', in On the Edge: Women's Experiences of Queensland, ed. Gail Reekie (Brisbane: University of Queensland Press, 1994), 66-7.

33 Neame, Diary of Arthur Neame, 34.

34 Queensland Registry of Births, Deaths, Marriages and Divorces (QRBDMD), registration details: $1875 / \mathrm{C} / 9$.

35 'Lower Herbert', Brisbane Courier (Trove), 23 October 1875, 7; 'The Exhibition', Brisbane Courier (Trove), 24 August 1876, 3; Peter Griggs, "Rust” Disease Outbreaks and Their Impact on the Queensland Sugar Industry, 1870-1880', Agricultural History, 69 (1995): 413-37.

36 'Early History: As told by an old pioneer', published in instalments in the Herbert River Express, 1947.

37 Spearritt, 'The Sexual Economics of Colonial Marriage', 66-7.
} 
White women and coloured alike experienced economic and sexual exploitation. Employment opportunities for white women in the Herbert were few, apart from those of domestic, housekeeper or companion, while marriage offered economic and sexual protection in a male-dominated society. However, there was little real protection as being a wife exposed women to exploitative obligations and transactions, particularly sexual, which were codified by colonial law. ${ }^{38}$ Aboriginal women made up the largest portion of female inhabitants on the Herbert. They were absorbed into the workforce not only as domestics but as field workers and, as female Melanesian indentured labourers were few, Melanesian men partnered with Aboriginal women. Single white men like Walter Scott and Stone were dependent on women's labour, in particular the white housekeepers and Indigenous women that they pressed into domestic roles.

Hotel keeping was one domain where women could secure independence and authority. Isabella Campbell and her new husband George Wickham went on to establish a hotel, the Planter's Retreat, in 1875 in an auspicious location, at the landing where passengers alighted for the road journey to the upper Herbert. Isabella employed Indigenous people and catered for the weddings of the local Chinese population. She benefited from the fact that in Australia hotel keeping by women was encouraged and legislated for and privileged women's 'rights as commercial traders over their sexual identities as women'. ${ }^{39}$ The woman hotelier, with her 'feminine qualities of dignity, hospitality, and maternal self-restraint', was regarded as an antidote to the disorderly drunkenness common in male-dominated frontier communities. ${ }^{40}$ Their autonomy in that space was rarely challenged, particularly as they had the backing of the Licensed Victuallers Association and the breweries. Isabella Campbell managed the Planter's Retreat in her own right from 1882 to 1892 . She would live out her life on the Herbert, dying there in 1902.

Another woman Isabella Mackenzie and Isabella Campbell were acquainted with was Elizabeth Burrows. Few personal facts are known but the sensational nature of her death meant that male writers recorded

38 Ibid., 67.

39 Clare Wright, Beyond the Ladies Lounge: Australia's Female Publicans (Melbourne: Melbourne University Press, 2003), 5, 17.

40 Claire Wright, 'Women Publicans (Australia)', in Alcohol and Temperance in Modern History. An International Encyclopedia, Vol. 1: A-L, eds. Jack S Blocker Jnr, David M Fahey and Ian R Tyrrell (Santa Barbara: ABC-CLIO, 2003), 682-3. 
it in detail. ${ }^{41}$ Elizabeth kept to herself and together with her husband, William George Conn, a small selector, lived on a picturesque but isolated selection they named the Hermitage. Elizabeth was 20 years younger than her husband. In this period in Queensland 48 per cent of women lived in rural areas, compared to 64.5 per cent of men, hence the high marriage rates in the Kennedy district. Given that sexual imbalance, marriage or common-law partnerships offered protection against sexual predation, for a woman to be younger than her husband was not unusual. The average marriage for a female in 1875 was 23 years. ${ }^{42}$ We will never know whether Elizabeth was with William for love or opportunity but she proved herself capable to take on the hard, physical work typical of small settlers and their families. Arthur Neame observed the Conns building a hut with William on the ground and Elizabeth on the roof putting on the thatch. ${ }^{43}$ Prior to 1875 there had been few violent confrontations between settlers and the Indigenous people on the lower Herbert; nevertheless, other settlers feared for the Conns' safety. The Conns trusted the Indigenous people and according to contemporary accounts treated them kindly. ${ }^{44}$ When they were brutally murdered by a group of Aborigines on the morning of 7 April 1875, retribution was immediate and merciless. The tragic consequence was that the actual perpetrators may have got away while many Aborigines who had nothing to do with the massacre, including women and children, were slaughtered. ${ }^{45}$

Louisa Buchanan was a contemporary of these women though none had the opportunity to call upon her services as midwife. Details of her life and work as a midwife are meagre. Arriving on the Herbert as a child, Louisa married Swedish immigrant Christian Anderssen (Anderson) in 1879. When Christian was invalided after sustaining a severe injury while shoeing a horse, Louisa turned to midwifery to support the family. She was self-taught. ${ }^{46}$ Midwifery, like hotel keeping, was a respectable profession for a woman and one to which women turned because of a need to earn

41 Johnstone, Spinifex \& Wattle, 58-60; Neame, Diary of Arthur Neame, 48; 'The Murder of Mr \& Mrs Conn on the Herbert River', Toowoomba Chronicle and Queensland Advertiser (Trove), 1 May 1875,3 .

42 Katie Spearritt, 'The Market for Marriage in Colonial Queensland', Hecate, 16, no 1/2

(30 November 1990): 23.

43 Neame, Diary of Arthur Neame, 48.

44 Ibid.; Barrie, Minding My Business, 67; Brisbane Courier (Trove), 14 May 1875, 3.

45 James Cassady, diary entry 20 May 1875, in Jas Cassady for FAO Cassady, JC/1 original notebook; 'Letters to the Editor', Queenslander (Trove), 4 September 1880, 306; 'Black v. White', Brisbane Courier (Trove), 7 October 1880, 5.

46 Finlay Skinner, Memories of a First World War Digger (Nambour: Finlay Skinner, 1981), 17. 
a living after being widowed or a husband being incapacitated. ${ }^{47}$ At that time, infant mortality rates in Queensland were one in eight before the age of one, and with a lack of qualified medical assistance to deal with birthing complications women, understandably, faced pregnancy and childbirth with considerable trepidation. ${ }^{48}$ Childbirth was considered women's business and women relied on each other, and white women even relied on their Indigenous and Melanesian domestics. Whether Louisa assisted women of colour, either in their confinements or postpartum, is not known. Despite enormous loss and hardship-the deaths of three children, an invalid husband, and children to raise-Louisa responded to calls for assistance at any hour of the day or night and was even known to have swum a river to attend to a woman in labour. ${ }^{49}$ Louisa lived to 84 , dying in 1948 in a nursing home in Charters Towers. She was predeceased by all but one of her seven children.

The contributions of these white women-Isabella Mackenzie, Isabella Campbell, Elizabeth Burrows and Louisa Buchanan-to the opening of the Herbert to European settlement and economic development are only mentioned in passing in the male record, making them virtually invisible to later researchers. This occurred whether they left the district, met an early death, or lived out their lives on the Herbert, and in spite of the fact that men and women alike depended on their multifarious skills. Housekeeper, planter, hotel keeper, midwife and small farmer; here, for the first time, these women have been identified, their lives fleshed out and their domestic and gendered contributions to the advancement of European settlement on the Herbert acknowledged as important.

\section{Women of Colour on the Herbert}

\section{Jenny}

Living alongside the white women whose lives have been recounted here were women of colour: Indigenous Aboriginal, Melanesian and Chinese. Though they occupied very different spaces socially, they could hardly have been unaware of each other. Manbarra (Palm Island) woman Jenny

47 Trisha Fielding, Neither Mischievous nor Meddlesome: The Remarkable Lives of North Queensland's Independent Midwives 1890-1940 (Townsville: North Queensland History Press, 2019), 3.

48 Spearritt, 'The Sexual Economics of Colonial Marriage', 69-70.

49 Skinner, Memories of a First World War Digger, 17. 
(Janny) lived on the pastoral property of James Cassady, which had been Njawaygi land; Annie Etinside in the home of a small selector; Eliza Jane Ah Bow in Chinatown in the vicinity of Isabella Campbell's Hotel. Alongside the white women, they were vital to sustaining and advancing human endeavour on the Herbert during the plantation era, often at great physical and emotional hardship.

Jenny would have been in her teens when those white women whose stories have been recounted above came to live on the Herbert. In their time, the Indigenous people's attitudes to the European incursion on their country went from cautious curiosity to fierce resistance to resigned acceptance. ${ }^{50}$ We can gain some idea of the traditional life of Indigenous women on the Herbert from the contemporary writings of naturalist Lumholtz and Robert Arthur Johnstone, Sub-Inspector of the Native Mounted Police. Contemporary newspaper depictions, both in Australia and overseas, of the Indigenous men and women on the Herbert tend to focus on the threat they represented and their 'barbarity', an image Lumholtz perpetrated rather than dispelled. ${ }^{51}$ Displaced and cut off from their traditional food sources, water supplies, trade routes and ceremonial grounds, they were subdued and 'let-in'. ${ }^{52}$ Retributive action taken by Europeans in response to Indigenous efforts to survive and resist the Europeans had reduced the Herbert Indigenous male population drastically, leaving an imbalance of men to women. ${ }^{53}$ By Jenny's time, women were clinging to traditional life while attempting to accommodate white cultural and economic practices and the expectations of white employers. Kate Atkinson, who relied on Indigenous women for heavy household tasks, complained that they were unreliable and prone to take off without warning. ${ }^{54}$ Her incomprehension was typical.

This was the situation when Jenny encountered Barnum and Bailey Circus agent Robert A Cunningham. People displaced and dispersed by colonisation were recruited to perform in Barnum and Bailey's travelling

50 An account of this progression is detailed in Cadet-James et al., Gugu Badhun: People of the Valley of Lagoons.

51 'Cannibals of Australia', San Francisco Call, 72, no. 115, 23 September 1892, 1.

52 'Keeping-out' entailed the forcible removal of Aboriginal people from land used by Europeans for pastoral or agricultural purposes; 'letting-in' happened when Aboriginal people ceased resisting and moved onto Europeans holdings and to the outskirts of towns where they became an important source of cheap labour.

53 Roslyn Poignant, Professional Savages: Captive Lives and Western Spectacle (Sydney: UNSW Press, 2004), 55.

54 Gilmore, On Eagles Wings, 85. 
circus, dime museums, fairgrounds and exhibitions in Europe and America. They performed alongside so-called human freaks and oddities. These displays fascinated European audiences. Among the performers, and of particular ghoulish fascination, were Indigenous Australians, who were portrayed as cannibals. ${ }^{55}$ The Indigenous Australians' displays of culture reinforced for white audiences their own technical advancement, while anthropologists took the opportunity to examine, measure and photograph the performers. Their findings generally supported contemporary ethnographic theories of white superiority compared to Aboriginal 'savagery'. ${ }^{56}$

We know of Jenny because of the painstaking research of Roslyn Poignant, who describes two groups of Indigenous Australians recruited from north Queensland. The first group of nine left Australia in 1883 and included two women. The second group of eight left in 1892 and also included two women, Jenny and Tottie (Dottie). ${ }^{57}$ What enticements were used by the recruiters, and to what degree they were coerced, is open to conjecture. However, kidnapping of Indigenous men, women and children by Europeans was common practice. ${ }^{58}$ In Gugu Badhun: People of the Valley of Lagoons, an entire chapter is dedicated to the practice. Cassady commented about it in a letter to the Queenslander where he wrote:

It is not a very uncommon thing for Native police officers to kidnap gins and boys. I know of a good many people in this locality that are indebted to Sub Inspector Armit for the black boy or gin they have got. ${ }^{59}$

On Cassady's arrival on the Herbert in 1873, he began voicing his concerns about the way he saw Indigenous men, women and children being treated by the Europeans, and the actions of the Native Police. He wrote letters to newspapers and to government representatives. An example of the correspondence entered into is to be found in the 'Black v. White' debate in letters to the editors of several Queensland newspapers.

55 'The Circus Napoleon: An Interesting Reminiscence of the late PT Barnum', Los Angeles Herald (CDNC), 36, no. 18, 5 May 1891, 5.

56 See Henry Reynolds, Frontier (Sydney: Allen and Unwin, 1987), 108-30.

57 Poignant, Professional Savages, 21, 204.

58 Raymond Evans, Kay Saunders and Kathryn Cronin, Race Relations in Colonial Queensland: A History of Exclusion, Exploitation and Extermination (Brisbane: University of Queensland Press, 1993), 102-17.

59 'Letters to the Editor: The Way we Civilize', James Cassady, Queenslander (Trove), 23 October 1880,530 . 
Cassady employed Indigenous and Melanesian men and women on his Fairview and Mungalla properties. On Mungalla they worked in the house, garden and stables, and lived in established communities on the property. ${ }^{60}$ These people saw him as a protector while the wider community vilified him, particularly the officers of the Native Mounted Police. Cassady stated: 'I was accused I constituted myself black protector for my own interests, and to the detriment of my neighbors' property. ${ }^{61} \mathrm{~A}$ neighbouring property was Molonga owned by Sub-Inspector Johnstone. Cassady was most critical of the Native Police and the superior officers, including Johnstone. For a man who offered safe haven on his properties to the Indigenous owners and Melanesians, it is understandable then that he was angry and demanded answers when in his absence some of the people from his Mungalla property were inveigled by Cunningham in 1892 to go with him to appear, ostensibly, in the World's Columbian Fair in Chicago in $1893 .{ }^{62}$

Jenny's group were recruited either from Mungalla or from Townsville where they may have gathered for ceremonial business. Jenny was accompanied by her husband Dilagroo or King Bill (also William or Bell). That he was a Njawaygi man can be identified by his body marks or scarifications. ${ }^{63}$ Njawaygi shared a close kinship system with the Manbarra of Palm Island and intermarriage was permitted. ${ }^{64}$ Jenny is likely to have been a domestic servant, and King Bill stated that he had worked with cattle for the European settlers. ${ }^{65}$ However, while only one of the group may have been a black tracker with the Native Mounted Police, they were all portrayed as such in the American press. ${ }^{66}$ That they originated from the Herbert is confirmed by reports that described the group as 'the Ingham blacks' and their scarifications as the 'favourite style of decoration $\ldots$ of the Ingham tribe'. ${ }^{67}$ The other woman in the group, Tottie, was the wife of a group member also called William and biological brother of King Bill. In addition to being Njawaygi, there is also suggestion that some members of the group could have been part Melanesian. ${ }^{68}$

60 Deidre Pope, New Beginnings: The Roche Family (Deidre Pope, 2017), 100-25.

61 'Letters to the Editor, 'Black v. White', Queenslander (Trove), 2 October 1880, 433.

62 Under Colonial Secretary to the Hon A S Cowley, 11 August 1896, QSA, 861465, 96/4761.

63 Poignant, Professional Savages, 205-6.

64 Ibid., 207.

65 'Held in Slavery on Coney Island', New York Journal (LOC), 19 July 1896, 36.

66 'The Boomerang Throwers', San Francisco Call (CDNC), 72, no. 115, 23 September 1892, 7.

67 'They Possess Sand', Los Angeles Herald (CDNC), 39, no. 103, 22 January 1893, 10.

68 Display panel, second group, Exhibit: Professional Savages. Captive Lives and Western Spectacle. Mungalla Station, Ingham. 
The Queensland authorities insisted on formalising the taking of eight Indigenous people out of the country. Cunningham was required to pay a security of $£ 500$ for their safe return, be able to account for their nonreturn, and prove that the group understood the terms of their agreement. ${ }^{69}$ Since the bond document is missing, it is unknown how Jenny's name, age and origin were recorded. ${ }^{70}$ Even given her good command of English, the degree of her complicity is to be questioned given the power imbalance prevailing between people of colour and whites. ${ }^{71}$ Jenny may have seen the opportunity to travel as a novel experience, but whether she understood the distances and the time that they were expected to be out of the country is another matter. Paperwork signed, the group were hurried on board the Peregrine. At Sydney, they were transhipped to the SS Monowai. Before they had even reached San Francisco in the last week of September, they were already wanting to return home. ${ }^{72}$ Provided with inadequate clothing, 'they huddled together and shivering with cold on the foredeck'. Jenny and Tottie each had only 'a thin shawl and petticoat and their thin limbs quite bare ... their eyes had a sad faraway look'. ${ }^{73}$ On arrival in San Francisco they were immediately put to work displaying their skills of boomerang throwing in Central Park. During the performance, Jenny and Tottie sat alone on the grandstand. They were now wearing 'calico garments and each wore an untrimmed red felt hat with a high dome-like crown'. ${ }^{74}$

Cunningham reported back that the group was happy and thriving, but complained that for his purpose of showcasing 'primitives' they were far too civilised. ${ }^{75}$ Nevertheless, despite their clearly civilised demeanour they were consistently described as 'man-eating. ${ }^{76}$ Portrayed as savages, they did not see themselves as such. As King Bill emphatically stated: "We are not savages although we are natives of a wild country. ${ }^{\text {'77 }}$ Initially they were feted and put up in fine hotels and performed in theatres and large grounds and halls. They were paid and, according to Cunningham,

69 Under Colonial Secretary WE Parry-Okeden to GA Roberts and Leu Solicitors, Townsville, 7 July 1892, QSA, 861429, 92/3922.

70 Poignant, Professional Savages, 211.

71 'Shivering Aborigines', San Francisco Call (CDNC), 2, no. 95, 3 September 1892, 2.

72 Ibid.

73 Ibid.

74 'Australian Aborigines Show How It Is Done', San Francisco Call (CDNC), 72, no. 115, 23 September 1892,5 .

75 'Townsville Blacks in America', Telegraph (Trove), 28 December 1892, 5; Poignant, Professional Savages, 217-18.

76 'The Boomerang Throwers', San Francisco Call (CDNC), 72, no. 115, 23 September 1892, 7.

77 'Held in Slavery on Coney Island', 36. 
were enjoying city life and the services and goods they could procure. ${ }^{78}$ Despite this, members of the group were in fact dying. While the climate of California had suited them, an American winter was another matter. It can only be imagined how Jenny felt when Tottie succumbed at the end of winter, 1893. By 1895 their number was reduced to four, possibly from the effects of exposure to the elements and neglect. While previously they had been applauded and had been able to give somewhat meaningful displays of their skills and culture, as time passed they were reduced to being exhibited in sideshow alleys and were living in cheap boarding houses in the slums. In the winter months they were left to their own devices. ${ }^{79}$ However their managers chose to view their charges' condition, the reality was very different. King Bill insisted that 'thousands of times we have complained about our pay and board, and begged, with tears, of Mr Trask [sic] to send us back, but he gave us no hope'.$^{80}$ King Bill and Jenny were very aware of the extent to which they were being exploited, and declared unequivocally that they knew that Cunningham's lifestyle in America was made at their expense. ${ }^{81}$ Nevertheless, they were compliant, doing what was asked of them. This compliance was extracted, in Poignant's view, with 'economic deprivation and manipulative brutality that undermined their sense of self-worth'. ${ }^{82}$ Already conditioned to this treatment on the Herbert, they were easy prey. King Bill's behaviour and words attested to this. Speaking to a New York Journal reporter in 1896, his eyes darted about in fear and he stated that when they have complained of their conditions of virtual imprisonment they were told to 'shut up' and that they 'couldn't do otherwise'. ${ }^{83}$

After the United States, they travelled on to Germany, the Netherlands, Sweden and Norway, though on leaving the US they may have thought they were going home. In 1896 three of the original group were still alive in Berlin: Jenny, King Bill and William (the husband of Tottie), at which time an anthropological examination was conducted. ${ }^{84}$ Somewhere after this time Jenny's husband King Bill died. According to one account,

\footnotetext{
78 Poignant, Professional Savages, 214-23.

79 Ibid., 219-27.

80 'Held in Slavery on Coney Island', 36.

81 Poignant, Professional Savages, 228, 234; 'The Palm Island Travellers', North Queensland Herald,

19 December 1898, 27.

82 Poignant, Professional Savages, 229.

83 'Held in Slavery on Coney Island', 36.

84 Rudolf Virchow et al., 'Drei Australier' (17 October 1896), Zeitschrift fur Anthropologie, Ethnologie und Urgeschichte, 28, 1896, 461-532.
} 
Jenny and William paid their own fares from Germany to England; an alternative account suggests that Cunningham paid them. From there, their fares back to Queensland were paid by the British government as deck passengers on the Duke of Portland, setting sail on 30 September $1898 .^{85}$ On arrival in Townsville they were met by the police and came under the Aboriginals Protection and Prevention of the Sale of Opium Act 1897, which had been enacted in their absence. ${ }^{86}$ This meant that they could not freely return to Mungalla and may have been immediately placed on a reserve or mission. The name Jenny is ubiquitous (one of the women in the 1883 group was also named Jenny), so tracing Jenny's whereabouts after arrival in Townsville is impossible, especially as correspondence regarding her situation between the Home Secretary and Townsville Police has not survived. ${ }^{87}$

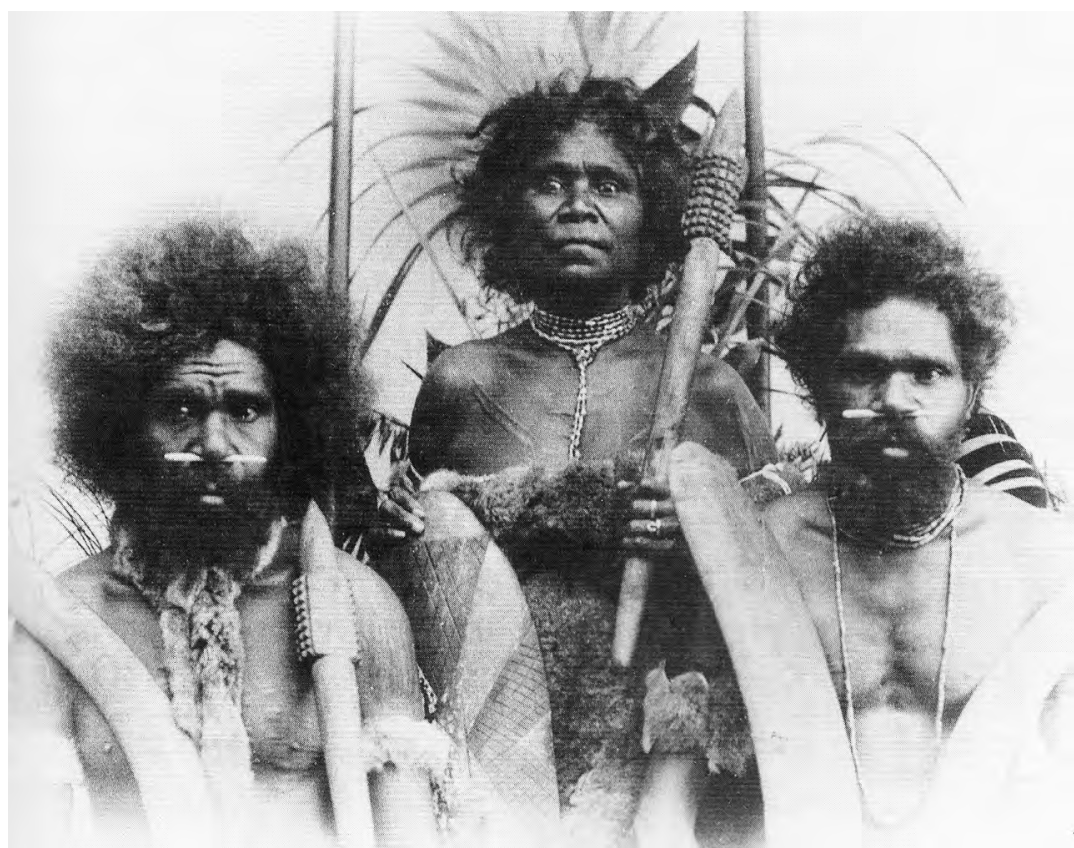

\section{Figure 1: (left to right) William, Jenny and King Bill.}

Source: Wilhelm Scharmann, Berlin, 1896 in Roslyn Poignant, Professional Savages:

Captive Lives and Western Spectacle (Sydney: UNSW Press, 2004), 233.

85 Poignant, Professional Savages, 234-5.

86 Aboriginals Protection and Preventions of the Sale of Opium Act, Qld, 1897.

87 Poignant, Professional Savages, 62, 235, 275. 
Though we know of Jenny's experiences under the supervision of Cunningham and other showmen, as is the case with all these invisible women in this account, we are left to imagine her emotions. We do know from newspaper articles that she found the long journey to America uncomfortable and was already wanting to go home. Once in America she would have felt denigrated as she listened to herself and her husband being described as 'true representatives of the lowest type of humanity'. ${ }^{88}$ Despair would have set in with the discomfort of cold winters, the growing disillusionment as their performances became less meaningful, their accommodation less salubrious and their pay less. Undoubtedly, she felt embarrassed as she was examined and photographed as an anthropological specimen. ${ }^{89}$ Finally, the enormous sorrow as she saw companion after companion, including her husband, succumb to death must have been overwhelming. Unable to return to her own Country, her homecoming was bittersweet. Jenny's story illustrates how one Aboriginal woman living on the Herbert in the plantation era attempted to determine a life for herself through accommodation of white cultural and economic practices, albeit with tragic consequences.

Jenny's story is important because she is an identified Indigenous woman who lived in the plantation era on the Herbert and survived the initial conflict between the Indigenous peoples and European interlopers. At the time of her encounter with Cunningham, she was contributing to the economy of the Herbert in her capacity as house servant; such domestic labour, even by white women, is too often obscured by the masculine biases of the historical record. What is all the more remarkable is that a reconstruction of a brief period of her life has been able to be made, especially given the period in which she lived and that the episode played out on distant shores. The irony is that once she returned to Australia she disappeared from the records. The prevailing racial attitude in the nineteenth and early twentieth centuries was that Aboriginals were 'intellectually at the bottom of the list of existing races comprising the human family'. ${ }^{90}$ Ethnographic and anthropological theories determined not only her recruitment by Cunningham, but the way overseas audiences perceived her. Those theories also underpinned Australian legislation in regards to the Indigenous population and enabled Jenny, and countless

88 'Shivering Aborigines,' 2.

89 Virchow, 'Drei Australier', 528-32.

90 Reynolds, Frontier, 78. 
Indigenous women like her, to be spirited away, out of anybody's memories. Today Jenny represents those invisible lives and by telling her story their manifold contributions are acknowledged.

\section{Annie}

Like Jenny, Annie Etinside Barslo, a Melanesian indentured labourer, was removed from her homeland, deprived of family and alienated from her culture. Despite the colour of her skin, which clearly betrayed her as non-white, the truth of her origins was hidden from her children and grandchildren. Melanesian women started arriving on the Herbert in the early 1880s, more than 10 years after the first Melanesian men had been brought to labour on the sugarcane fields of the Herbert. ${ }^{91}$ They were employed not only as housemaids but in the field, and described as executing the task 'very deftly'. ${ }^{92}$ As not all indentured labourers chose to return home at the end of their indenture, some continued on as timeexpired labour and a community of them formed a small village near the town of Halifax. Finlay Skinner wrote of how his mother always spoke of her admiration of the women of that village, and particularly of the three who 'adopted' her when, as a young mother, she spent long hours alone when her husband was working on the farm. They would be with her every day offering her help and companionship. ${ }^{93}$ However, not all Melanesian woman were automatically one of that community. Rachel Garlando writes that Annie would live out her life on the Herbert outside the experience of the rest of the Melanesian community. ${ }^{94}$

Annie's origins are clouded by inconsistent record keeping. Patricia Mercer calculates that the number of women and children transported as indentured labourers was few..$^{95}$ Annie's story suggests that some women may have entered the country identified as male. Annie's island of origin and her arrival date are unknown and over the period of her lifetime in various documents her geographic origins have been recorded differently. Similarly, her actual age cannot be verified. The only Etinside on the Pacific Island Immigration Queensland register was a male recruited

91 Robert Shepherd, 'The Herbert River Story: The Kanak Struggle', Herbert River Express, 23 January 1992, 5 [reprint, first published, 1957].

92 'Sugar Industry', Sydney Mail and New South Wales, 18 October 1884, 791.

93 Skinner, Memories of a First World War Digger, 19.

94 Garlando, 'Annie Gosling', 3.

95 Patricia Mary Mercer, 'The Survival of the Pacific Islander Population in North Queensland, 1900-1940' (PhD, The Australian National University, 1981), 10, 91. 
on 5 November 1888 from Ureparapara (the third largest island in the Banks group of northern Vanuatu) - the same island recorded on her headstone.${ }^{96}$ In family folklore, she was accompanied by a brother, though there is no official record confirming that. ${ }^{97}$ Among the local Australian South Sea Islander community there is even an assertion that she was the daughter of a Melanesian man and an Aboriginal woman and had been born on Palm Island. ${ }^{98}$ If she was 78 in 1948, as her death certificate states, and she was the 'male' recruited in 1888, then she would have been around 18 when she arrived in Australia. If she had been 67 years in Australia, again as recorded on her death certificate, she would have been indentured in 1881 and around 11 years old.

Female indentured labourers worked in the field and in settlers' homes. On arrival on the Herbert, Annie was indentured to Norwegian Johan (John) Ingebright Alm and his wife Antonia. ${ }^{99}$ Family recollections have her working for Englishman Francis Herron and his wife Lucinda. ${ }^{100}$ Both Alm and Herron were small farmers. Her next position was housemaid to the single George Gosling, another small farmer, who had migrated from Britain to Australia in $1881 .{ }^{101} \mathrm{He}$ had been an overseer of indentured labour gangs, farmed on leased land and then farmed in his own right a piece of land called Poverty Flat by the locals because it was considered useless for farming purposes. ${ }^{102}$ That he created a 'model farm' there was tribute to both Gosling and Annie's efforts, as small farmers depended on wives and children for all field labour apart from harvesting the cane. ${ }^{103}$

While housekeeping for Gosling, Annie would bear him two children. The birth records of her children are the first official record bearing the name Etenside (misspelt). Garlando speculates why they may have married in 1898 after the birth of the second child. ${ }^{104}$ In the absence of official indenture records Annie could have been identified as Aboriginal. Under the Aboriginal Protection and Restrictions of the Sale of Opium Act 1897, her movements and with whom she could associate would have been restricted

96 List of Pacific Island Labourers, LII-I 1865-1904, in Register of Pacific Island Immigration Queensland, QSA, image 23968.

97 Garlando, 'Annie Gosling', 8.

98 Ibid., 9.

99 'Obituary. The late Annie Gosling', Herbert River Express, 30 November 1948, 4.

100 Garlando, 'Annie Gosling', 8.

101 Ibid., 11.

102 'Halifax', Northern Miner, 18 August 1899, 8.

103 'Halifax', North Queensland Register (Trove), 21 August 1899, 48; Vidonja Balanzategui, 'Small Sugar Farmer Agency in the Tropics 1872-1914', 107-8.

104 Garlando, 'Annie Gosling', 14-19. 
and her children, as mixed race and born out of wedlock, could have been taken from her. ${ }^{105}$ Melanesian labour was never intended to be a permanent solution to the labour problem, nor were the Melanesian people to be permitted to settle permanently in Australia. ${ }^{106}$ Marriage to Englishman George Gosling gave her and her children protection. On the other hand, if identified as an indentured labourer, without the protection of marriage to Gosling, she and her children could have been forcibly repatriated. As early as 1892, the Queensland government indicated its intent to end indenture and repatriate those Melanesian labourers remaining in Queensland. Again, marriage to Gosling may have given her immunity. ${ }^{107} \mathrm{~A}$ further three children were born after their marriage. Then, on 17 January 1905, when the youngest was only eight days old, Gosling died of malaria. On his death Annie inherited land and goods worth $£ 1,700 .{ }^{108}$

In 1907 she gave birth to a baby she named Robert Gosling. Two years later she married William John Davey on 17 February 1909. Robert was likely to have been Davey's son. With Gosling's premature death, with a young family to support and a small farm to run, did she turn to William Davey, another European, for physical help on the farm? Tragically, one month after her marriage to Davey on 20 March 1909, she registered the death of Robert (providing no father's name). ${ }^{109}$ Davey was also dead by 30 August of the same year. ${ }^{110}$

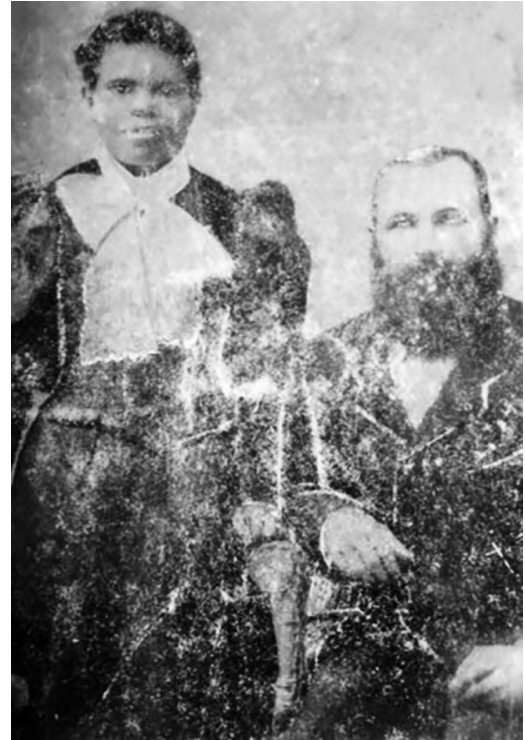

Figure 2: Annie Gosling (née Etinside Barslo) and George Gosling, 1885.

Source: Albert and Rachel Garlando.

105 Aboriginal Protection and Restrictions of the Sale of Opium Act 1897.

106 Vidonja Balanzategui, 'Small Sugar Farmer Agency in the Tropics 1872-1914', passim; Balanzategui, The Herbert River Story, 69-71.

107 Queensland Government, Pacific Island Labourers (Extension) Act, Qld, 1892.

108 'Returned', Morning Post (Trove), 12 July 1905, 2.

109 QRBDMD, registration details: 1909/C/620.

110 Ibid., 1909/C/531 and 1909/C/639. 
Tracey Banivanua-Mar states that settlement and economic development of tropical north Queensland by Europeans was rationalised by racial theories and attitudes that sanctioned violence, social segregation and ultimately forced repatriation. ${ }^{11}$ Those prevailing theories and attitudes may explain why Annie hid from her children that she was Melanesian with the result that her grandchildren had no idea they were descended from a Melanesian woman. Legislation dictated that only those former indentured labourers with a Certificate of Exemption could remain in Australia after 1907. Annie does not appear to have been granted a certificate of exemption, yet she remained and became a respected member of the Halifax community. Though her skin colour betrayed her as being other than white, she concealed or lost her heritage and her children were able to pass as white. Legal documents, the electoral role, newspaper reports, Annie's obituary and family accounts indicate that Annie did not experience the discrimination and prohibitions that other people of colour did. She inherited all of George's estate as his lawful widow and participated in civic life, was registered on the electoral role, and conducted a farm. Her children, meanwhile, all attended the Halifax State School, her male sons farmed and held jobs at the Colonial Sugar Refining Company (CSR) sugar mills (which was unusual for children of former indentured labourers), and her children married not only Anglo-Australians, but Europeans and Asians. ${ }^{12}$ Annie did 'not appear to be constrained by her ethnicity' as a Melanesian and was able to pass her children off as European. ${ }^{113}$ The cost, however, was her and her descendants' complete disassociation from the Melanesian community.

Annie's life was one of contradictions, and details of her life are elusive. There were fewer women indentured labourers on the Herbert than in other areas, so Annie could have easily found a partner from among the Melanesian community. ${ }^{114}$ Yet she did not. But as there were fewer white women to men on the Herbert perhaps it is not surprising that George

111 Tracey Banivanua-Mar, 'Stabilising Violence in Colonial Rule: Settlement and the Indentured Labour Trade in Queensland in the 1870s', Labour History, 113 (2017): 9-29; Tracey Banivanua-Mar, Violence and Colour: The Australian-Pacific Indentured Labour Trade (Honolulu: University of Hawai' $\mathrm{i}$ Press, 2007).

112 Mercer notes that as a migrant Annie would have had no voting rights and presumes that, as Annie Gosling disappeared from the electoral roll after 1908 when her name was first recorded, the authorities had caught up with the discrepancy. However, what Mercer missed was that Annie continued on the roll as Annie Davey.

113 Garlando, 'Annie Gosling', 20.

114 Mercer, 'Survival of a Pacific Islander Population', 78. 
Gosling married his Melanesian housekeeper. Though convenient for both, it could have been expected that he would face severe disapproval from the white community. Yet in Annie's obituary it is indicated that their relationship did not diminish opinions of him and rather he was remembered as 'well known and respected'. ${ }^{15}$ Meanwhile, forcible displacement meant that Annie had to live out her life apart from her own kin and family, resulting in a loss of heritage. Until the threat had passed, she had to live with the fear of forcible deportation. As a result, she determinedly raised her children as white in order to protect them from social rejection and racial slurs. So effective was she that on her daughter Elizabeth Rose's wedding to Frederico Garlando in 1925, a detailed report of the wedding featured in both the Herbert River Express (HRE) and the Townsville Bulletin. ${ }^{116}$ When Annie died on 23 November 1948 she was legally Annie Davey, though after Davey's death she reverted to Gosling and her obituary in the HRE was for the late Annie Gosling. There she was described as a 'grand old pioneer'. ${ }^{117}$ Annie's intriguing story adds a female dimension to the Melanesian indentured labourer's experience on the Herbert. The number of Melanesian labourers on the Herbert as repatriation measures came into force in 1906 were 14 Melanesian women and 500 men. ${ }^{118}$ The significance of having such a fulsome account of her life is underscored by the small number of Melanesian women who were recruited to the Herbert and, in turn, remained there. Her story illustrates how one Melanesian woman living on the Herbert in the plantation era attempted to determine a life for herself and her children through accommodation of male-dominated white cultural and economic practices.

\section{Eliza}

Eliza Jane Ah Bow and Annie would have undoubtedly recognised each other as they passed in the main street of Halifax. Like Annie, Eliza, who was the daughter of a Chinese father and an Irish mother, was caught between two cultures. Large numbers of Chinese men were employed on the sugar plantations on the Herbert in the 1880s, supplementing the Melanesian indentured labour force. The majority came from rural

115 'Obituary: The Late Annie Gosling', 4.

116 'Family Notices Wedding Garlando-Gosling', Townsville Daily Bulletin (Trove), 4 December $1925,7$.

117 'Obituary: The Late Annie Gosling', 4.

118 Mercer, 'Survival of the Pacific Islander Population', 78. 
communities in the Guangdong Provence in the Southern Pearl Delta. ${ }^{119}$ In 1884 there were as many as 640 employed by the sugar mills, and by 1885 the Chinese population on the Herbert was described as 'numerous and prosperous'. ${ }^{120}$ Included were 25 Chinese families. ${ }^{121}$ Chinatowns were established at Cowden (Wickham's property) with commercial centres in East Ingham and in Halifax. ${ }^{122}$ Not only did the men labour for others, they were also market gardeners, shopkeepers and sugar farmers in their own right. But the Herbert was dominated by sugar growing and there was little agricultural diversification, so the bulk of the Chinese population was engaged in the industry as employees or as farmers. With the restrictions imposed by the White Australia Policy legislation (1901) and the Sugar Bounty Acts (1903 and 1905), which mandated that sugar be grown and harvested using only white labour, Chinese people were essentially forced off the Herbert. ${ }^{123}$ Europeans on the Herbert would not have normally acknowledged the Chinese residing there as 'pioneers'; however, Alec S Kemp, an early resident on the Herbert, listed both Chinese and Europeans settlers as pioneers in his memoir. In an unusual sentiment for a European in the time, he wrote that 'its [sic] a pity they left the area'. ${ }^{124}$ He described in detail the Joss House in Halifax and the shops that were 'a wonderland of enchantment for child and adult alike'. He recalled, 'the lovely little sloe eyed girls, "like lovely little frightened fawns", dressed in their picturesque chinese [sic] costumes, helping to serve when times were busy'. ${ }^{125}$

The girls Kemp described were likely to have been born in Australia of mixed marriages, as wives and children of married men remained behind in China, often never to be seen again. ${ }^{126}$ The first Chinese-born woman to settle on the Herbert did so in $1911 .{ }^{127}$ Chinese men married white migrant women, but they endeavoured to marry their daughters to fellow

119 Sandi Robb, 'Chinese Families', Exhibition banner in Rediscovering Buk Ti: Chinese settlers in the lower Herbert Valley (Ingham Family History Association Inc: Exhibition February 2019).

120 Pugh's Almanac and Queensland Directory (Brisbane: Gordon \& Gotch, 1884); 'A Winter Tour in Queensland', Argus (Trove), 24 October 1885, 4.

121 Robb, 'Chinese Families'.

122 Jan Wegner and Sandi Robb, 'Chinese in the Sugar: A Case Study from the Ingham District', in Northern Links: Chinese in Tropical Australia, eds. Sandi Robb and Kevin Rains (Ipswich: Chinese Heritage in Northern Australia (CHINA) Inc., 2014), 8-9; Gossner and Robb, 'Lee Hop'.

123 Wegner and Robb, 'Chinese in the Sugar', 11-13.

124 Kemp, The Kemp Report, 27.

125 Ibid.

126 Robb, 'Chinese Families'.

127 Gossner and Robb, 'Mar Gee'. 
Chinese. ${ }^{128}$ James Ah Bow married Irish immigrant Ellen Bridget O’Daly in Townsville in 1875, where their four children were born. On their move to Chinatown at Cowden, James ran a market garden. ${ }^{129}$ There their son Patrick went to school, though it is unclear whether their daughters ever did. The girls did, however, lead active social lives. ${ }^{130}$

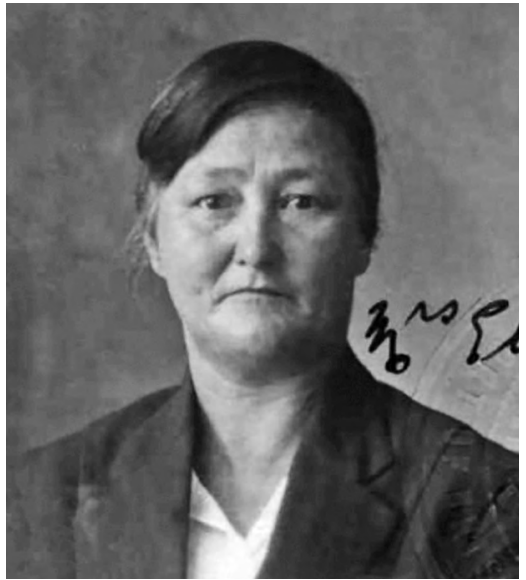

Figure 3: Elizabeth Jane Look Hop (née Ah Bow) 1925.

Source: National Archives of Australia, NAA: Series no. J2483, 391/45, Certificate Exempting from Dictation Test (CEDT), 14 November 1925.
At some point, Eliza Jane, the oldest daughter, met Lee Look Hop (Thomas Look Hop). On arrival in Queensland, Thomas was drawn by the gold rush to the Palmer River, later moving to the lower Herbert where he opened a shop behind the Planter's Retreat. ${ }^{131}$ His neighbours were the Ah Bow family. It is not recorded how his marriage to Eliza was arranged or if she was complicit. What is known, however, is the fact that Eliza was already pregnant before the marriage and Thomas was a prominent eligible man in Chinatown. ${ }^{132}$ Eliza married Thomas at the Planter's Retreat on 5 June $1891 .{ }^{133}$ She was only 13 years of age, though she was recorded as 14 on the marriage record. ${ }^{134}$ Four months after her marriage she gave birth to her first child at home. ${ }^{135}$ At the age of 18 she lost both her parents, at 19 she lost a younger sister, and at the age

128 Robb, 'Chinese Families'.

129 Gossner and Robb, 'Ah Bow'.

130 Ibid.

131 Gossner and Robb, 'Lee Look Hop'.

132 Ibid.

133 QRBDMD, registration details: 1891/C/352.

134 Ibid., 1878/C/5247; Gossner and Robb, 'Lee Look Hop'. Further information on Eliza can also be obtained through the records of Hinchinbrook Shire Council cemetery.

135 QRBDMD, registration details: 1891/C/2227. 
of 21, in 1899, she left on the first of her trips to China. ${ }^{136}$ Travelling with her and Thomas were their five children (the youngest being eight months). ${ }^{137}$ In China they lived in the village of Loong Dou, Zhongshan, where they remained until 1909. ${ }^{138}$ On their return to the Herbert, she gave birth to four more children the youngest of whom was only six months old when Thomas died in 1912. ${ }^{139}$ Two years later she gave birth to another child, Cornelius Daly Lee (the surname having been shortened from Look Hop to Lee). No father was recorded. ${ }^{140}$ She outlived her husband by 49 years, dying in Townsville on 27 August 1961 as Elizabeth Jane Lee. ${ }^{141}$ Her children retained strong connections with the village and family in China, some living their adult lives there, others visiting for lengthy periods or, in the case of James, her first son, balancing both countries and their customs. ${ }^{142} \mathrm{He}$ maintained a large house in China and had two wives, which he brought to Australia after the Second World War. ${ }^{143}$

In her lifetime, Eliza demonstrated pluck, a sense of adventure, sustained hard work and persistence, no less so than the Chinese men we know so much more about. Eliza endured much from a very young age, beginning with marriage to an older man and childbirth when she was still a child. She experienced frequent childbearing and suffered the death of her mother and sister when she most needed them. She fearlessly faced the perils of nineteenth-century sea travel with children, including an infant, and life in a foreign country far distant from the Herbert and her brother and sister. Her husband's early death left her with a young family to support and yet she survived all that to live to 83 years of age. Where the Chinese experience is invariably recorded in terms of the men's contribution to the sugar industry and commerce, Eliza's life story offers a more nuanced version of the Chinese experience on the Herbert in the plantation era.

136 Gossner and Robb, 'Lee Look Hop'.

137 Ibid.

138 Gossner and Robb, 'Ah Bow'.

139 QRBDMD, registration details: 1911/C/2143, 1912/C/710.

140 QRBDMD, registration details: 1914/C/2442.

141 Ibid., 1961/C/4636. Further information can also be obtained through the records of Belgium

Gardens Cemetery, Townsville.

142 Gossner and Robb, 'Lee Look Hop'.

143 Ibid. 


\section{Conclusion}

In this article, the lives of these women who lived in the Herbert Valley during the plantation era of the late nineteenth century have been fleshed out, informed by the often two-dimensional descriptions given by European men, and supplemented by the few records left by women themselves, and other primary sources and secondary scholarship. Theirs was an invisible narrative running parallel to the well-documented one of men's exploits; their stories add to our knowledge of the gender history of this period and challenge the notion of the frontier as an entirely masculine landscape. When they appear in the primary accounts of men, they do so briefly and are often regarded with pity if they are white or contempt if they are coloured. With this account, a group of women, white and of colour, living alongside each other in plantation-era tropical north Queensland have been identified and their contributions rightly acknowledged; they were not bystanders and observers, and were certainly not pitiable or contemptible. Rather, they were strong, active participants in, and survivors of, the drama of colonisation that opened the Herbert to white settlement, displaced the Indigenous land owners, and melded cultures from across the globe. 
This text is taken from Lilith: A Feminist History Journal: Number 26, published 2020 by ANU Press, The Australian National University,

Canberra, Australia.

doi.org/10.22459/LFHJ.26.07 